\title{
CULICINE MOSQUITOES (DIPTERA: CULICIDAE) COMMUNITIES AND THEIR RELATION TO PHYSICOCHEMICAL CHARACTERISTICS IN THREE BREEDING SITES IN EGYPT
}

\author{
Noura A. Elhawary; Mohamed A. Soliman; Amal I. Seif; Wesam S. Meshrif* \\ Zoology Department, Faculty of Science, Tanta University, Gharbia, Egypt
}

\begin{tabular}{l} 
Article History: \\
Received: 27 August 2020 \\
Accepted: 23 September 2020 \\
Published Online: \\
\hline 06 October 2020 \\
Keywords: \\
Breeding sites \\
Culicine mosquitoes \\
Egypt \\
Physicochemical properties \\
Species community \\
*Correspondence: \\
Wesam Meshrif \\
Zoology Department \\
Faculty of Science \\
Tanta University \\
Gharbia, Egypt \\
E-mail: \\
wmeshrif@science.tanta.edu.eg
\end{tabular}

Article History:

Received: 27 August 2020

Published Online:

06 October 2020

Keywords:

Breeding sites

Culicine mosquitoes

Egypt

Physicochemical properties

*Correspondence:

Wesam Meshrif

Zoology Department

Faculty of Science

Tanta University

E-mail:

wmeshrif@science.tanta.edu.eg

\section{INTRODUCTION}

Vector-borne diseases account for more than $17 \%$ of all infectious diseases. So, vectors are responsible for more than 700000 deaths yearly ${ }^{[1]}$. Insects represent most vectors of diseases among humans and
Mosquitoes have diverse species and global distribution. Most freshwater bodies support different mosquito species breeding. The physicochemical characteristics of mosquito breeding sites may influence culicine species distribution and their abundance. This study aimed to determine culicine species communities and their abundance in two rural sites and one urban breeding site in Egypt considering physicochemical characteristics of breeding places. These areas were Al-Beshlawy drainage canal (Giza), El-Khartoum irrigation ditch (Beheira), and Tanta man-made ground hole (Gharbia), respectively. The measured physicochemical parameters were temperature, $\mathrm{pH}$, salinity, turbidity, dissolved oxygen, and nitrite. Diversity indices (recorded number of species, diversity, equitability, and concentration of dominance) of mosquitoes were also calculated. The results showed that six culicine species were identified in the tested three breeding sites. These were Culex pipiens, $C x$. univittatus, $C x$. antennatus, $C x$. quinqueifasciatus, Cx. perexiguus, and Culiseta longiareolata. All species are native to the Egyptian fauna. In all tested urban and rural breeding sites, $C x$. pipiens was considered eudominant. Bray-Curtis dissimilarity in the culicine community between the tested sites ranged between 0.03 and 0.12 . This dissimilarity may be attributed to the absence of certain species in some sites, as well as the significant difference in the abundance of $C x$. pipiens and Cs. longiareolata among the sites. Water salinity and dissolved nitrite content differed significantly among the breeding sites. The multiple regression analysis between the identified culicine species and the physicochemical parameters showed that salinity, nitrite content, turbidity, and $\mathrm{pH}$ are considered key factors to predict some culicine species in water bodies. their domestic animals ${ }^{[2]}$. Mosquitoes are the primary vectors of serious diseases including malaria, filariasis, dengue fever, rift valley fever, yellow fever, Zika fever, chikungunya fever, Japanese encephalitis, and West Nile fever among humans ${ }^{[3-5]}$. 
In general, twenty-nine mosquito species belong to Anopheles, Culex, Culiseta, Ochlerotatus, and Uranotaenia genera were native to Egypt $^{[6-10]}$. They infested all rural and urban areas ${ }^{[11-14]}$. Mosquitoes have great diversity and abundance worldwide and are in close contact with a man and his domestic animals ${ }^{[15]}$. They can breed in any type of natural or artificial aquatic habitats, including ponds, marshes, floodwaters, storm drains, old tires, and water in tree holes. Mosquito larvae breed in habitats with a wide range of physicochemical characteristics, like salinity, turbidity, nitrate, dissolved organic matter, water temperature, hydrogen ion concentration, dissolved oxygen (DO) values, and sunlight ${ }^{[16]}$.

The physicochemical characteristics may influence oviposition, survival, and distribution of mosquito species. Each species has its specific oviposition and breeding sites. The breeding water of Aedes sp. exhibited higher oxygen content than those of Culex and Anopheles ${ }^{[17]}$. $C x$. pipiens complex may withstand different degrees of water pollution, while Culiseta longiareolata aggregates in high salinity and alkaline water ${ }^{[18,19]}$. The temperature has a great effect on the biology of Cx. pipiens larvae $^{[20]}$. Thus, monitoring programs and regular surveys on water bodies may provide essential information about the suitability of breeding sites to diverse numbers of mosquito species. The agricultural activities and urbanization such as rice cultivation, watering, and fish farming have led to spread of various species of mosquitoes ${ }^{[21]}$. Though some studies have examined several culicine breeding sites and their physicochemical characteristics in some Egyptian Governorates ${ }^{[13,14,22]}$; fragmentary information is available about other water bodies and Governorates in Egypt. Thus, the present study aimed to explore species communities of culicine mosquitoes and their relative abundance in correlation to physicochemical characteristics of mosquito breeding habitats in rural (Giza and Beheira Governorates) and urban (Gharbia Governorate) areas in Egypt. The results could help to predict culicine species communities in similar sites based on their identified physicochemical parameters. Precise knowledge of the mosquito ecology and identification of mosquito larvae species is of great importance to improve vector control programs ${ }^{[17,23]}$.

\section{MATERIAL AND METHODS \\ Study areas and sampling sites}

Mosquito larvae were collected from rural and urban breeding habitats in three Egyptian Governorates (Figure 1). The rural mosquito breeding sites were in Giza Governorate (Abu Rawash Village) and Beheira Governorate (El-Khartoum Village). The urban breeding site was in Gharbia Governorate (Tanta University campus). These mosquito breeding sites were selected mainly according to geographic basis.

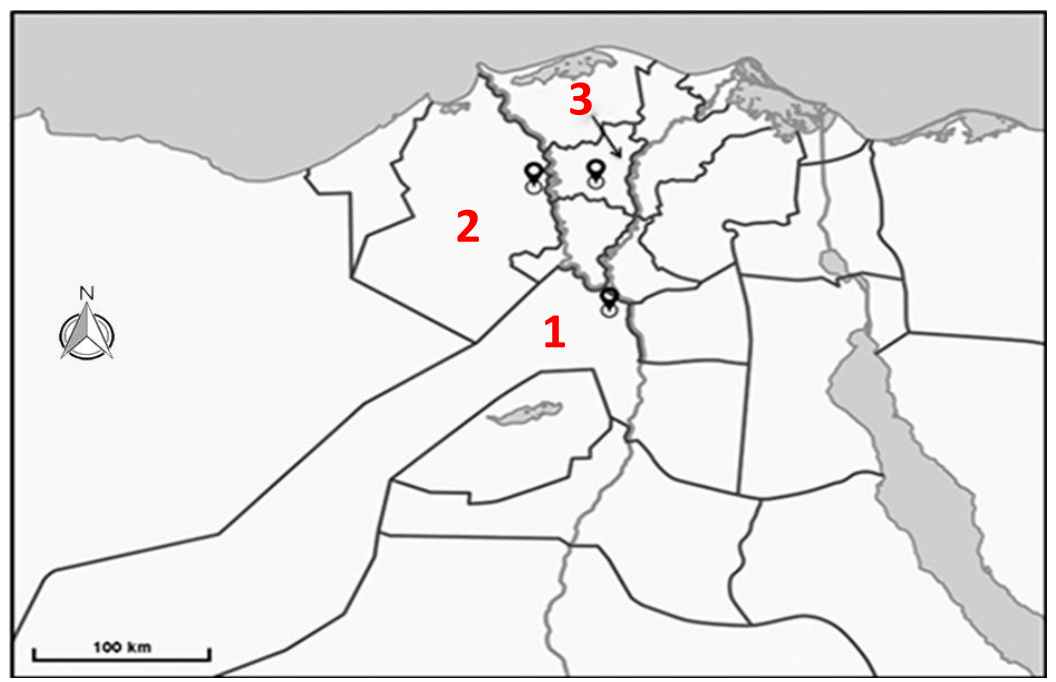

Figure 1: Map of mosquito sampling sites in Giza (1), Beheira (2), and Gharbia (3) Governorates, Egypt. 
Abu Rawash village is an archaeological area (ruined pyramids of Djedefre), located 8.0 kilometres north of the International Tourist Giza Governorate. This small village is considered a rural area where the inhabitants are mainly involved in agriculture, livestock husbandry, snake hunting, and tourism handwork industry. Mosquitoes were collected from Al-Beshlawy open drainage canal (located 30 $2^{\prime} 54.157^{\prime \prime} \mathrm{N}$ latitude and $31^{\circ} 5$ '56.162"E longitude) with a width of about 2-7 $\mathrm{m}$ and a depth of $2 \mathrm{~m}$. Its length is about $3.05 \mathrm{~km}$. The water surface is dominated by water hyacinths and algae. Drainage canal is much polluted with sewage and industrial waste, surrounded by residential areas, fodder factories and breeding domestic animals farms (Figure 2A).

El-Khartoum village (Beheira Governorate) is also considered as a rural area located west of the Nile Delta. Mosquitoes were collected from an irrigation ditch (located 30 33'21.116"N latitude and $30^{\circ} 39^{\prime} 53.319 " \mathrm{~g}$ longitude) with $1.0 \mathrm{~m}$ width and $50 \mathrm{~cm}$ depth. Its length is about $1.5 \mathrm{~km}$. The water-body contains agricultural wastes, as being surrounded by agricultural areas (alfalfa and castor trees) and domestic animals breeding farms (Figure 2B).

The convention campus of Tanta University site is located in the centre of Tanta City, Gharbia Governorate. This area is an urban site that encompasses various sectors of workforces including shops, restaurants, hospitals service, and faculties. Mosquito samples were collected from a stagnant man-made ground hole near to Faculty of Science (located 3048'5.339"N latitude and $30^{\circ} 59^{\prime} 36.114 " \mathrm{E}$ longitude) with a width of $1.0 \mathrm{~m}$ and depth of $1.0 \mathrm{~m}$. It contains rain and drainage water (Figure 2C).
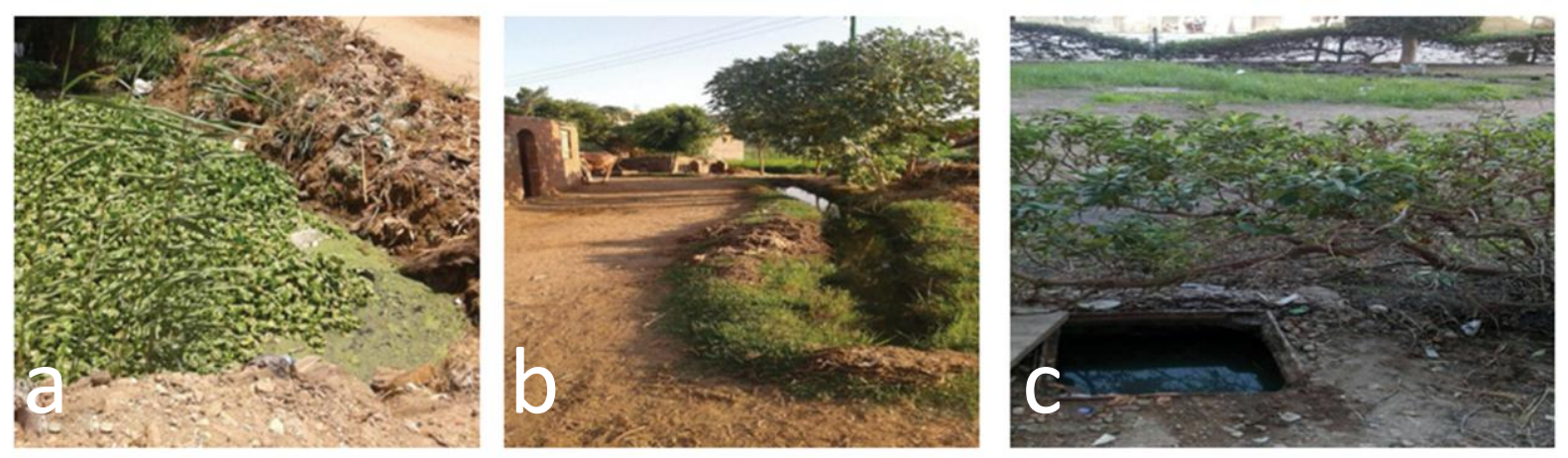

Figure 2: Landscape photographs of surveyed mosquito habitats: (a) Al-Beshlawy drainage canal in a rural agricultural area of Abu Rawash, (b) El-Khartoum irrigation ditch in a rural settlement area, (c) an urban man-made ground hole near Tanta University campus.

\section{Larval and water sampling}

Mosquito larval sampling was conducted during June - August 2017. In each site, mosquito larvae were collected by standard $350 \mathrm{~mL}$ plastic dipper according to the protocol of $\mathrm{WHO}^{[24]}$. After each dipper, the collected larvae were transferred to glass jars with enough air for respiration. Concurrently, water samples were collected in glass bottles for physicochemical analysis. Five dips were taken from Al-Beshlawy drainage irrigation canal and El-Khartoum irrigation ditch breeding sites at a distance of $200 \mathrm{~m}$ from each sample location. In the man-made ground hole, samples were sequentially taken at once. Containers were labelled and transported to the laboratory after each sampling.

\section{Culicine identification, classification, and ecological parameters}

To identify the collected mosquito' species, hundred living third instar larvae were identified per dip/site $(\mathrm{N}=500)$. Larvae 
were examined by a compound light microscope Optic 10 lab (Ray wild limited company, Germany). Larvae were identified by morphological characteristics described in Harbach's pictorial key ${ }^{[25]}$. Several calculations were made to have Bray-Curtis' dissimilarity, recorded number of species, their diversity, equitability, and concentration of dominance in different sites. BrayCurtis dissimilarity $\left(\mathrm{BC}_{\mathrm{d}}\right)$ was determined according to the equation of Bray and Curtis $^{[26]}$ :

$B C_{d}=\frac{\sum\left|n_{i}-n_{j}\right|}{\sum\left(n_{i}+n_{j}\right)}$

Where $n i$ and $n_{j}$ are the numbers of individuals counted of species in sites $i$ and $j$, respectively.

Species diversity and equitability (E) were calculated as described in Mwangangi et al. ${ }^{[27]}$ using Shannon-wiener diversity index $\left(\mathrm{H}^{\prime}\right)$ according to the following equations:

$H^{\prime}=-\sum\left[p_{i} * \ln \left(p_{i}\right)\right]$

Where $P_{i}$ is the number of individuals of species $i$ divided by the total number of all species.

$E=H^{\prime} / \ln (S)$

Where $S$ is the total number of species

The concentration of dominance (CD) was calculated as described by Thakur and Khare $^{[28]}$ according to the equation:

$C D=\sum\left(\frac{n_{i}}{N}\right)^{2}$

Where $n_{i}$ is the number of individuals of species; and $(\mathrm{N})$ is the total number of all species.

\section{Physicochemical analysis of water samples}

Maximum and minimum air temperature after meteorological data was $29-43^{\circ} \mathrm{C}$, $26-37^{\circ} \mathrm{C}$, and $17-25^{\circ} \mathrm{C}$ in Giza, Beheira, and Gharbia Governorates, respectively. Water temperature was calculated according to the equation of Preud'homme and Stefan ${ }^{[29]}$ :

$T_{w}=5.0+0.75 T_{\alpha}$

Where $T_{w}$ is the water temperature, while $T_{a}$ is the air temperature.
The water $\mathrm{pH}$ was measured using a pH meter (model: $6173 \mathrm{pH}$, JENCO Instruments Inc., San Diego, CA, USA). Salinity percentage and turbidity, nephelometric turbidity unit, (NTU) were measured using a conductivity meter HI 2300 and turbidimeter HI 98703, respectively (Hanna Instruments Inc., Smithfield, RI, USA). The DO content $(\mathrm{mg} / \mathrm{L})$ in water was measured by standard methods of American Public Health Association ${ }^{[30]}$. In brief, a volume of $2 \mathrm{~mL} \mathrm{MnSO}_{4}$ solution and alkaline iodide reagent was added to $300 \mathrm{~mL}$ water sample. The mixture was re-stoppered to completely exclude air bubbles and mixed several times. After precipitation, the precipitate was contacted with seawater for 10 minutes. After it settled down, the clear supernatant was produced; the stopper was carefully removed and immediately $2 \mathrm{~mL}$ of concentrated $\mathrm{H}_{2} \mathrm{SO}_{4}$ was added then the bottle was stoppered and mixed by gentle inversion to make a solution. In a glass flask, $203 \mathrm{~mL}$ of the sample was titrated with $0.025 \mathrm{Eq} / \mathrm{L}$ $\mathrm{Na}_{2} \mathrm{~S}_{2} \mathrm{O}_{3}$ to a pale straw colour; then $2 \mathrm{~mL}$ freshly prepared starch solution was added and the titration was continued to the first disappearance of the blue colour. As $1.0 \mathrm{~mL}$ of $0.025 \mathrm{Eq} / \mathrm{L} \mathrm{Na} \mathrm{Na}_{2} \mathrm{O}_{3}$ is equivalent to $0.2 \mathrm{mg}$ of oxygen, so $5 \mathrm{~mL}$ of $\mathrm{Na}_{2} \mathrm{~S}_{2} \mathrm{O}_{3}$ was equivalent to the $\mathrm{mg} / \mathrm{L}$ of $\mathrm{DO}$.

Nitrite level (mg/L) was measured by the standard environmental protection agency methods ${ }^{[31]}$. The samples were filtered through a 0.45-pm-pore-diameter filter membrane to remove the suspended solids. The $\mathrm{pH}$ value was adjusted to 5-9 with $1.0 \mathrm{Eq} / \mathrm{L} \mathrm{HCl}$ and $2 \mathrm{~mL}$ of colour reagent was added to $50 \mathrm{~mL}$ sample and mixed. Absorbance of samples and standards were measured at $543 \mathrm{~nm}$ after $30 \mathrm{~min}$ against water blank. A blank was prepared by adding $50 \mathrm{~mL}$ of nitrite-free distilled water and $2 \mathrm{~mL}$ of colour reagent. A standard curve was prepared by plotting absorbance of standards against $\mathrm{NO}_{2}-\mathrm{N}$ concentration. The concentration of samples was calculated using the regression line equation produced from the curve. The determinations of $\mathrm{pH}$, salinity (\%), turbidity, DO, and nitrite 
contents were repeated three times in water samples.

\section{Ethics statement}

The protocol was approved by the Research Ethics Committee of the Faculty of Science, Tanta University (permit no. 0164). All experiments were performed in the Animal Facility of Zoology Department, Faculty of Science, Tanta University.

\section{Statistical analysis}

Data were expressed as mean \pm standard deviation. Response variables were checked for normality using Shapiro-Wilk test and Bartlett's test for homogeneity of variances. The similarity between culicine species communities in breeding sites was calculated using Bray-Curtis' test. The differences in the physicochemical parameters and species percentage among sites were tested using Kruskal-Wallis test. In the case of significant difference, a post-hoc analysis was performed using Wilcoxon test combined with Bonferroni correction. One-way ANOVA was used to compare the differences of salinity and Nitrite content parameters among sites. Tukey's test was used for pairwise analysis between the tested sites. For multiple comparisons, the $P$ values were adjusted according to Bonferroni correction to control the familywise error rate. Multiple regression analysis was carried out to explore the association between culicine species and physicochemical variables. Statistical analysis was performed using $\mathrm{Rcmdr}$ package in $\mathrm{R}$ software, Version 3.6. $1^{[32]}$.

\section{Results \\ Culicine species communities in the breeding sites}

A total of 1500 larvae were sampled from Al-Beshlawy drainage canal, ElKhartoum irrigation ditch, and Tanta manmade ground hole. Five culicine species were identified in Al-Beshlawy drainage canal (Table 1). They were Culex pipiens Linnaeus (95.0\%), Cx. univittatus Theobald (2.6\%), Cx. antennatus (Becker) (1.2\%), $C x$. quinqueifasciatus Say (0.8\%), and $C x$. perexiguus Theobald $(0.4 \%)$. Three species were identified in Beheira breeding site: Cx. pipiens (97.6\%), Cx. antennatus $(1.6 \%)$, and $C x$. univittatus $(0.8 \%)$. Five species were identified in Tanta manmade ground hole. They were $C x$. pipiens (85.6\%), Cs. longiareolata Macquart (6.0\%), CX. univittatus $(4.6 \%), C x$. antennatus (3.2\%), and Cx. quinqueifasciatus $(0.6 \%)$.

Table 1: Percentages (mean \pm standard deviation) of identified culicine larvae in Al-Beshlawy drainage canal (Giza), El-Khartoum irrigation ditch (Beheira), and Tanta manmade ground hole (Gharbia).

\begin{tabular}{llllr}
\hline & $\begin{array}{c}\text { Al-Beshlawy } \\
\text { Drainage canal }\end{array}$ & $\begin{array}{c}\text { El-Khartoum } \\
\text { irrigation ditch }\end{array}$ & $\begin{array}{c}\text { Tanta man-made } \\
\text { ground hole }\end{array}$ & $P$-value \\
\cline { 2 - 5 } Culex pipiens & $95.0 \pm 2.9^{\mathrm{a}}$ & $97.6 \pm 2.8^{\mathrm{a}}$ & $85.6 \pm 4.2^{\mathrm{b}}$ & $<0.001$ \\
Culex univittatus & $2.6 \pm 1.8^{\mathrm{a}}$ & $0.8 \pm 1.3^{\mathrm{a}}$ & $4.6 \pm 4.0^{\mathrm{a}}$ & 0.124 \\
Culex antennatus & $1.2 \pm 0.8^{\mathrm{a}}$ & $1.6 \pm 1.5^{\mathrm{a}}$ & $3.2 \pm 2.5^{\mathrm{a}}$ & 0.332 \\
Culex quinquefasciatus & $0.8 \pm 0.4^{\mathrm{a}}$ & $0.0^{\mathrm{a}}$ & $0.6 \pm 0.9^{\mathrm{a}}$ & 0.070 \\
Culex perexiguus & $0.4 \pm 0.9^{\mathrm{a}}$ & $0.0^{\mathrm{a}}$ & $0.0^{\mathrm{a}}$ & 0.368 \\
Culiseta longiareolata & $0.0^{\mathrm{b}}$ & $0.0^{\mathrm{b}}$ & $6.0 \pm 4.1^{\mathrm{a}}$ & 0.001 \\
\hline
\end{tabular}

a,b: values with same small letter in same row show no significant difference at $P \geq 0.025$ (Wilcoxon test combined with Bonferroni correction). Species dominance: eudominant $>30 \%$, dominant $10-30 \%$, subdominant $5-10 \%$, minor $1-5 \%$, and rare $<1 \%$ according to Engelmann ${ }^{[33]}$. 
In the three breeding sites, $C x$. pipiens was considered eudominant, while $C x$. antennatus appeared to be minor. In AlBeshlawy drainage canal, $C x$. antenntus and $C x$. univittatus were minor, while $C x$. quinqueifasciatus and $C x$. perexiguus were rare. In El-Khartoum irrigation ditch, among the identified three species only $C x$. univittatus was rare. In Tanta man-made ground hole, Cs. longiareolata was subdominant, both $C x$. antennatus and $C x$. univittatus were minor, and
Cx. quinqueifasciatus was rare, as shown in Table "1".

Bray-Curtis' dissimilarity showed that all breeding sites tested were similar to each other (Table 2). However, the highest dissimilarity was recorded between ElKhartoum irrigation ditch and Tanta man-made ground hole with an index of 0.12; while the lowest dissimilarity was observed between El-Khartoum irrigation ditch and Al-Beshlawy drainage canal hole with an index of 0.03 .

Table 2: Bray-Curtis dissimilarity matrix among breeding sites: Al-Beshlawy drainage canal (Giza), El-Khartoum irrigation ditch (Beheira), and Tanta man-made ground hole (Gharbia).

\begin{tabular}{lccc}
\hline & $\begin{array}{c}\text { Al-Beshlawy } \\
\text { drainage canal }\end{array}$ & $\begin{array}{c}\text { El-Khartoum } \\
\text { Irrigation ditch }\end{array}$ & $\begin{array}{c}\text { Tanta man-made } \\
\text { ground hole }\end{array}$ \\
\cline { 2 - 4 } Al-Beshlawy drainage canal & & 0.03 & 0.10 \\
El-Khartoum irrigation ditch & 0.03 & & 0.12 \\
Tanta man-made ground hole & 0.10 & 0.12 & \\
\hline
\end{tabular}

Ecological parameters (diversity indices) in the sites

Several diversity indices including species diversity, equitability, and concentration of dominance were calculated in the breeding sites (Table 3). Tanta man-made ground hole had the highest value of culicine mosquito diversity and equitability, while ElKhartoum irrigation ditch had the lowest values. The highest dominance concentration value was reported in El-Khartoum irrigation ditch, while the lowest value was in Tanta man-made ground hole.

Table 3: Number of culicine species, diversity, equitability, and concentration of dominance in the breeding sites: Al-Beshlawy drainage canal (Giza), El-Khartoum irrigation ditch (Beheira), and Tanta man-made ground hole (Gharbia).

\begin{tabular}{lccc}
\hline & $\begin{array}{c}\text { Al-Beshlawy } \\
\text { drainage canal }\end{array}$ & $\begin{array}{c}\text { El-Khartoum } \\
\text { Irrigation ditch }\end{array}$ & $\begin{array}{c}\text { Tanta man-made } \\
\text { ground hole }\end{array}$ \\
\cline { 2 - 4 } Number of species & 5 & 3 & 5 \\
Species diversity & 0.26 & 0.13 & 0.58 \\
Equitability & 0.14 & 0.07 & 0.33 \\
Concentration of dominance & 0.90 & 0.95 & 0.74 \\
\hline
\end{tabular}

The physicochemical parameters of the breeding sites

Physicochemical characteristics of mosquito breeding sites are important to determine the suitability of the environment for mosquitoes.
One-way ANOVA results showed significant differences among the breeding sites in salinity $(\%)$ and dissolved nitrite content $\left(F_{2,6}=50.25, p<0.001\right.$ and $F_{2,6}=5.87, p=0.039$, respectively). Tukey's 
test showed that salinity (\%) in sites exhibited significant differences in pairwise comparison (Table 4). Regarding dissolved nitrite content, El-Khartoum irrigation ditch exhibited higher $(P<0.05)$ nitrite content than in rural Giza breeding site. Otherwise, $\mathrm{pH}$, turbidity, and DO content showed no significant differences among the three breeding sites.

Table 4: Physicochemical parameters (mean \pm standard deviation) of breeding sites: Al-Beshlawy drainage canal (Giza), El-Khartoum irrigation ditch (Beheira), and Tanta manmade ground hole (Gharbia).

\begin{tabular}{lccc}
\hline & $\begin{array}{c}\text { Al-Beshlawy } \\
\text { drainage canal }\end{array}$ & $\begin{array}{c}\text { El-Khartoum } \\
\text { Irrigation ditch }\end{array}$ & $\begin{array}{c}\text { Tanta man-made } \\
\text { ground hole }\end{array}$ \\
\cline { 2 - 4 } Temperature & $32.00 \pm 7.42^{\mathrm{a}}$ & $28.63 \pm 5.83^{\mathrm{a}}$ & $20.75 \pm 4.24^{\mathrm{a}}$ \\
$\mathrm{pH}$ & $8.11 \pm 0.42^{\mathrm{a}}$ & $7.85 \pm 0.71^{\mathrm{a}}$ & $7.79 \pm 0.13^{\mathrm{a}}$ \\
Salinity (\%)*** & $3.37 \pm 0.45^{\mathrm{a}}$ & $1.33 \pm 0.25^{\mathrm{b}}$ & $5.10 \pm 0.61^{\mathrm{c}}$ \\
Turbidity (NTU) & $11.10 \pm 11.57^{\mathrm{a}}$ & $5.69 \pm 3.84^{\mathrm{a}}$ & $3.86 \pm 4.39^{\mathrm{a}}$ \\
DO (mg/L) & $0.33 \pm 0.58^{\mathrm{a}}$ & $0.30 \pm 0.44^{\mathrm{a}}$ & $0.73 \pm 0.12^{\mathrm{a}}$ \\
Nitrite (mg/L)* & $0.20 \pm 0.09^{\mathrm{a}}$ & $0.98 \pm 0.40^{\mathrm{b}}$ & $0.40 \pm 0.35^{\mathrm{ab}}$ \\
\hline
\end{tabular}

NTU: nephelometric turbidity unit, DO: dissolved oxygen content. ****: refer significant differences among means in sites at $P<0.05$ and $P<0.001$, respectively. ${ }^{\mathrm{a}-\mathrm{c}}$ : values with the same small letter in same row are not significantly different at $P \geq 0.025$ (One-way ANOVA with Tukey's post-hoc test and Bonferroni correction).

\section{Association between culicine species relative abundance and physicochemical characteristics}

The stepwise multiple regression analysis indicated an association between most physicochemical parameters in the breeding sites and the relative abundance of the culicine species. Of the five variables examined, four variables (salinity, $\mathrm{pH}$, turbidity, and nitrite) were important predictors for the identified culicine species. The results indicated that salinity was the most important predictor for four culicine species abundance.

Cx. pipiens abundance appeared negatively associated with salinity $\left(R^{2}=0.787\right.$, $P=0.001)$; predicted abundance $=-0.01931$ (salinity) + 2.02815. However, both $C x$. univittatus and $C x$. antennatus abundances were positively associated with salinity $\left(R^{2}=0.55, \quad P=0.023 ; R^{2}=0.55\right.$, $P=0.022) . \quad C x$. univittatus predicted abundance $=0.18022$ (salinity) -0.23456 , whereas predicted abundance of $C x$. antennatus $=0.13359$ (salinity) -0.01855 . Concerning $C x$. quinqueifasciatus, it was inversely related to nitrite $\left(R^{2}=0.78\right.$, $P=0.002)$; predicted abundance $=-0.42826$ (nitrite) +0.00534 . Cx. Perexiguus was positively associated with both turbidity and $\mathrm{pH} \quad\left(R^{2}=0.72, \quad P=0.025\right.$ and $P=0.044$, respectively); predicted abundance $=0.19764(\mathrm{pH})+0.24017$ (turbidity) - 1.66854. Regarding Cs. longiareolata, it had a positive association with both salinity and nitrite $\left(R^{2}=0.83\right.$, $P=0.002$ and $P=0.017$, respectively); predicted abundance $=0.28708$ (salinity) +0.75985 (Nitrite) -0.35780 .

\section{DISCUSSION}

Six culicine species were identified in the current study in the tested breeding habitats (Giza, Beheira, and Gharbia Governorates). These were $C x$. pipiens, $C x$. univittatus, $C x$. antennatus, $C x$. quinqueifasciatus, $C x$. 
perexiguus, and Cs. longiareolata. In Giza, Al-Beshlawy drainage canal community consisted of the first five species of Culex, whereas El-Khartoum irrigation ditch community consists of only $C x$. pipiens, $C x$. Univittatus, and Cx. Antennatus, and Tanta man-made ground hole community consisted of $C x$. pipiens, $C x$. univittatus, $C x$. antennatus, $C x$. quinqueifasciatus, and Cs. longiareolata. Similarly, Mostafa et al. ${ }^{[34]}$, Abdel-Hamid et al. ${ }^{[12]}$, and AbdelHamid et $a l .{ }^{[13]}$ identified the same species in different Governorates in Egypt. The observed differences in species communities between the tested breeding sites were checked using Bray-Curtis dissimilarity test. Bray-Curtis matrix showed low dissimilarity among the breeding sites in the culicine species. The lowest dissimilarity was recorded between El-Khartoum irrigation ditch and Al-Beshlawy drainage canal, while the highest dissimilarity was recorded between El-Khartoum irrigation ditch and Tanta man-made ground hole. This dissimilarity could be attributed to the observed differences in the abundance of $C x$. pipiens, $C x$. quinqueifasciatus, Cx. perexiguus, and Cs. longiareolata in these sites. According to the number of species identified and their percentages, El-Khartoum irrigation ditch had the least diversity with only three recorded species, while Tanta manmade ground hole had the highest diversity, and Al-Beshlawy drainage canal was intermediate in diversity, equitability, and dominance. The intermediate levels in this site could be explained by the action of competition that regulates diversity. The three sites had low equitability values that defined as the extent of the representation by equal numbers of individuals of different species of a given community. This is obviously because of the high percentages of $C x$. pipiens in all tested breeding sites, which in turn led to the high concentration of dominance in the three breeding sites. The concentration of dominance was mostly clear in El-Khartoum irrigation ditch site, as a consequence of a low number of species occupied this breeding site. To explain the suitability of the sites to the inhabiting species, the physicochemical characteristics of these sites were also determined.

In the present study, the temperature range recorded in the three breeding sites was $21-32.00^{\circ} \mathrm{C}$. So, culicine mosquitoes seem to adapt to this wide range of temperatures. These results agreed with Kenawy et al. ${ }^{[23]}$ who observed a temperature range of $17-30^{\circ} \mathrm{C}$ for $C x$. pipiens, $C x$. perexiguus, Ochlerotatus caspius, $C x$. pusillus, and Cs. longiareolata in Cairo Governorate, Egypt. The results indicate that the $\mathrm{pH}$ of the sampled breeding sites in rural and urban areas was slightly alkaline and ranged between 7.79 and 8.11. These results agreed with Pelizza et $a .^{[35]}$ and Oyewole et al. ${ }^{[36]}$ who found that mosquito larvae preferred neutral or slightly alkaline water. Water salinity exhibited significant differences among mosquito breeding habitats in Beheira, Giza, and Gharbia with values of $1.33,3.36$, and 5.1, respectively. The high salinity in Gharbia urban breeding site might be attributed to anthropogenic activities and salts inflows in drainage water ${ }^{[37]}$. Culicine mosquitoes are reported to prefer fresh-water for oviposition ${ }^{[38]}$. In the present study, the presence of five species in the high salinity water may reflect adaptation to the breeding site. The water turbidity values of breeding sites ranged from 3.86 to 11.1 NTU. In other words, mosquitoes colonized aquatic habitats with wide ranges of turbidity. The low turbidity in Gharbia urban site maybe because it is a man-made hole with restricted drainage. Culicine larvae preferred turbid water ${ }^{[39]}$. Kenawy et al. ${ }^{[23]}$ found that $C x$. pipiens, $C x$. perexiguus, and $C x$. pusillus tolerated highly turbidity. Unexpectedly, DO levels were low in the three breeding sites with a range of $0.3-0.73 \mathrm{mg} / \mathrm{L}$. Similar results were reported in Kenya ${ }^{[40]}$ and Russia ${ }^{[41]}$. Low DO levels in the three sites may be due to anthropogenic activities like sewage discharge, leaching from farmland and agriculture, as well as microbial activities and decomposition of organic matters. This explanation was suggested by Popoola and 
Otalekor $^{[42]}$. Silberbush et al. ${ }^{[43]}$ suggested that when DO levels decreased in water, larvae seek access to atmospheric oxygen for development. The dissolved nitrite concentrations were $0.19,0.39$, and $0.98 \mathrm{mg} / \mathrm{L}$ in Al-Beshlawy drainage canal, Tanta man-made ground hole, and El-Khartoum irrigation ditch sites, respectively. The high nitrite concentration in El-Khartoum irrigation ditch may be explained by excesses of nitrogenous agricultural wastes, fertilizers, and human and domestic animal faeces drained into water $^{[44]}$. Kenawy et al. ${ }^{[23]}$ found $C x$. pipiens, and Cs. longiareolata breeding in water with nitrite levels of $0.04-0.23 \mathrm{mg} / \mathrm{L}$ in Cairo Governorate. To link between species relative abundance in the sites and the physicochemical characteristics, a stepwise multiple regressions analysis was also performed in the current study.

It is known that the relative abundance of some culicine mosquitoes is correlated with environmental variables. So, the categories described by Engelmann ${ }^{[33]}$ based on the numerical dominance of a species could be explained. In all breeding sites, Cx. pipiens was considered eudominant species similar to the previous reports ${ }^{[12,23,34]}$. The highest abundance was recorded in El-Khartoum irrigation ditch, despite that the highest nitrite content was detected. These results are consistent with the information reported in Kuwait by Salit et al. ${ }^{[18]}$ that $C x$. pipiens can tolerate different degrees of nitrite content. Cs. longiareolata was subdominant species and identified only in Tanta manmade ground hole. Cs. longiareolata larvae showed a positive association with salinity as appeared in the multiple regression analysis. Similarly, Salit et al. ${ }^{[18]}$ in Kuwait and Messai et al. ${ }^{[19]}$ in Algeria found that Cs. longiareolata tolerated high salinity levels. CX. univittatus was minor in Tanta man-made ground hole and Al-Beshlawy drainage canal, but rare in El-Khartoum irrigation ditch, as it had a positive correlation with salinity. $C x$. antennatus was a minor, and $C x$. quinqueifasciatus was rare due to high alkalinity. Abdel-Hamid et al. ${ }^{[12]}$ also found that larval densities decreased as $\mathrm{pH}$ increased. The only appearance of $C x$. perexiguus in Al-Beshlawy drainage canal was attributed to $\mathrm{pH}$ and turbidity as reported in the multiple regression analysis. Adebote et $a l .^{[45]}$ and Dejenie et $a l .{ }^{[46]}$ reported that culicine larvae were positively associated with the $\mathrm{pH}$.

In conclusion, the results indicated that salinity is the best indicator for abundance of $C x$. pipiens, Cx. univittatus, Cx. antennatus, and Cs. longiariolata. Nitrite predicts larval densities of $C x$. quinqueifasciatus and $C s$. longiariolata; whereas, turbidity and $\mathrm{pH}$ are common indicators for $C x$. perexiguus abundance.

\section{ACKNOWLEDGMENTS}

Authors express their deep thank to the staff of the Health Ministry Regional Labs in Tanta, Gharbia and Tanta University Central Lab for assistance in the physicochemical measurements. The present work has not received any funding. The authors declare that they have no conflict of interest.

\section{AUTHORS' CONTRIBUTIONS}

MAS, AIS, and WSM conceived and designed research. NAE and WSM conducted experiments. WSM analysed data. All authors wrote and approved the manuscript.

\section{REFERENCES}

[1] WHO (2014). A Global Brief on Vector-Borne Diseases, Document number: WHO/DCO/WHD/2014.1. World Health Organization, Geneva, Switzerland.

[2] Darwish, M. and Hoogstraal, $H$. (1981). Arboviruses infecting humans and lower animals in Egypt: a review of thirty years of research [19501980]. J Egypt Public Health Assoc, 56(1-2): 1-112.

[3] Gad, A. M.; Hassan, M. M.; El Said, S. et al. (1987). Rift Valley fever virus transmission by different Egyptian mosquito species. Trans R Soc Trop Med Hyg, 81(4): 694-698. 
[4] Harb, M.; Faris, R.; Gad, A. M. et al. (1993). The resurgence of lymphatic filariasis in the Nile delta. Bull World Health Organ, 71: 49-54.

[5] Turell, M. J. (2012). Members of the Culex pipiens complex as vectors of viruses. J Am Mosq Control Assoc, 28: 123-126.

[6] Kirkpatrick, T. W. (1925). The Mosquitoes of Egypt. Government Press, Cairo, Egypt.

[7] Gad, A. M. and Darwish, R. O. (1957). Mosquitoes collected in southern Sinai. Bull Ent Soc Egypt, 41: 533538.

[8] El-Said, S. and Kenawy, M. (1983). Anopheline and culicine mosquito species and their abundance in Egypt. J Egypt Public Health Assoc, 58: 108142.

[9] Harbach, R. E.; Harrison, B. A.; Gad, A. M. et al. (1988). Records and notes on mosquitoes (Diptera: Culicidae) collected in Egypt. Mosquito Systematics, 20(3): 317-342.

[10] Gad, A. M.; Harbach, R. E. and Harrison, B. A. (2006). Anopheles (Cellia) ainshamsi, N. sp. (Diptera: Culicidae), a saltwater species from the Red Sea coast of Egypt. Proc Entomol Soc Wash, 108(2): 366380.

[11] Harbach, R. E. (1988). The mosquitoes of the subgenus Culex in southwestern Asia and Egypt (Diptera: Culicidae). Contrib Am Entomol Inst, 24: 1-236.

[12] Abdel-Hamid, Y. M.; Soliman, M. I. and Allam, K. M. (2009). Spatial distribution and abundance of culicine mosquitoes in relation to the risk of filariasis transmission in El Sharqiya Governorate, Egypt. Egypt Acad J Biol Sci (E. Medical Entom \& Parasitology) 1: 39-48.

[13] Abdel-Hamid, Y. M.; Soliman, M. I. and Kenawy, M. A. (2011). Geographical distribution and relative abundance of culicine mosquitoes in relation to transmission of lymphatic filariasis in El Menoufia Governorate,
Egypt. J Egypt Soc Parasitol, 41: 109118.

[14] Abdel-Hamid, Y. M.; Soliman, M. I. and Kenawy, M. A. (2011). Mosquitoes (Diptera: Culicidae) in relation to the risk of disease transmission in El Ismailia Governorate, Egypt. J Egypt Soc Parasitol, 41(2): 347-356.

[15] Rueda, L. M. (2008). Global diversity of mosquitoes (Insecta: Diptera: Culicidae) in freshwater. Hydrobiologia, 595: 477-487.

[16] Clements, A. N. (1992). The Biology of Mosquitoes. Volume 1: Development, Nutrition and Reproduction. Chapman \& Hall, London, UK.

[17] Sehgal, S. and Pillai, M. (1970). Preliminary studies on the chemical nature of mosquito-breeding waters in Delhi. Bull World Health Organ, 42(4): 647-650.

[18] Salit, A. M.; Al-Tubiakh, S. S.; El-Fiki, S. A. et al. (1996). Physical and chemical properties of different types of mosquito aquatic breeding places in Kuwait State. Proceedings of the Second International Conference on Urban Pests, 185-193.

[19] Messai, N.; Aouati, A. and Berchi, S. (2016). Impact of the surface water physicochemical parameters on Culicidae (Diptera: Nematocera) of lakeside ecosystem "Sebkhet Ezzemoul" (Oum El Bouaghi Algeria). J Entomol Zool Stud, 4(3): 391-398.

[20] Zayed, A. B.; Mostafa, A. A.; Moselhy, W. A. et al. (2019). Influence of temperature change on the growth and susceptibility of the common house mosquito, Culex pipiens in Egypt to some insecticides. International Journal of Ecotoxicology and Ecobiology, 4(2): 42-50.

[21] Amusan, A. A. S.; Mafiana, C. F.; Idowu, A. B. et al. (2005). Sampling mosquitoes with CDC light trap in rice field and plantation communities in 
Ogun State, Nigeria. Tanzania Health Research Bulletin, 7: 111-116.

[22] Kenawy, M.; Rashed, S. S. and Teleb, S. (1998). Characterization of rice field mosquito habitats in Sharkia Governorate, Egypt. J Egypt Soc Parasitol, 28(2): 449-459.

[23] Kenawy, M. A.; Ammar, S. E. and Abdel-Rahman, H. A. (2013). Physico-chemical characteristics of the mosquito breeding water in two urban areas of Cairo Governorate, Egypt. Journal of Entomological and Acarological Research, 45(3): e17 (DOI: 10.4081/jear.2013.e17).

[24] WHO. (1975). Manual of Practical Entomology in Malaria. Part II: Methods and Techniques. World Health Organization, Geneva, Switzerland.

[25] Harbach, R. E. (1985). Pictorial keys to the genera of mosquitoes, subgenera of Culex and the species of Culex (Culex) occurring in southwestern Asia and Egypt, with a note on the subgeneric placement of Culex deserticola (Diptera: Culicidae). Mosquito Systematatics, 17(2): 83107.

[26] Roger Bray, J. and Curtis, J. T. (1957). An ordination of the upland forest communities of southern Wisconsin. Ecological monographs, 27(4): 325349.

[27] Mwangangi, J. M.; Midega, J.; Kahindi, S. et al. (2012). Mosquito species abundance and diversity in Malindi, Kenya and their potential implication in pathogen transmission. Parasitol Res, 110: 61-71.

[28] Thakur, A. S. and Khare, P. K. (2006). Species diversity and dominance in tropical dry deciduous forest ecosystem. Journal of Environmental Researh and Development, 1: 26-31.

[29] Preud'homme, E. B. and Stefan, H. G. (1992). Relationship Between Water Temperatures and Air Temperatures for Central US Streams. St. Anthony
Falls Hydraulic Laboratory, Minneapolis, MN, USA.

[30] APHA; FSIWA and AWWA (1955). Standard Methods for the Examination of Water, Sewage, and Industrial Wastes. American Public Health Assoc, Inc., New York, NY, USA.

[31] Kopp, J. F. and McKee, G. D. (1979). Methods for Chemical Analysis of Water and Wastes, EPA-600/4-79020. National Technical Information Service, Springfield, VA, USA.

[32] R Development Core Team (2019). R: A Language and Environment for Statistical Computing. R Foundation for Statistical Computing, Vienna, Austria.

[33] Engelmann, H.-D. (1978). "On classification of dominance of soil arthropods." Pedobiologia, 18(5-6): 378-380.

[34] Mostafa, A. A.; Allam, K. A. M. and Osman, M. Z. (2002). Mosquito species and their densities in some Egyptian governorates. J Egypt Soc Parasitol, 32: 9-20.

[35] Pelizza, S. A.; López Lastra, C. C.; Becnel, J. J. et al. (2007). Effects of temperature, $\mathrm{pH}$ and salinity on the infection of Leptolegnia chapmanii Seymour (Peronosporomycetes) in mosquito larvae. J Invertebr Pathol, 96: 133-137.

[36] Oyewole, I. O.; Momoh, O. O.; Anyasor, G. N. et al. (2009). Physicochemical characteristics of Anopheles breeding sites: impact on fecundity and progeny development. Afr J Environ Sci Technol, 3(12): 447-452.

[37] Williams, W. D. (2001). Anthropogenic salinisation of inland waters. Hydrobiologia, 466: 329-337.

[38] Iasiukevich, V. V. (1997). The relation of the degree of water salinity to oviposition by female blood-sucking mosquitoes. Med Parazitol (Mosk), 2: 32-35.

[39] Sattler, M. A.; Mtasiwa, D.; Kiama, M. et al. (2005). Habitat characterization and spatial distribution of 
Anopheles sp. mosquito larvae in Dar es Salaam (Tanzania) during an extended dry period. Malar J, 4: 4 (DOI: 10.1186/1475-2875-4-4).

[40] Muturi, E. J.; Mwangangi, J.; Shililu, J. et al. (2007). Mosquito species succession and physicochemical factors affecting their abundance in rice fields in Mwea, Kenya. J Med Entomol, 44(2): 336-344.

[41] Vinogradova, E. B. (2000). Culex pipiens pipiens mosquitoes: taxonomy, distribution, ecology, physiology, genetics, applied importance and control. Pensoft Publishers, Sofia, Bulgaria.

[42] Popoola, K. O. K. and Otalekor, A. (2011). Analysis of aquatic insects' communities of Awba reservoir and its physico-chemical properties. Res J Environ Earth Sci, 3(4): 422-428.
[43] Silberbush, A.; Abramsky, Z. and Tsurim, I. (2015). Dissolved oxygen levels affect the survival and developmental period of the mosquito Culex pipiens. J Vector Ecol, 40(2): 425-427.

[44] WHO. (2011). Guidelines for Drinking-Water Quality. World Health Organization, Gutenberg, Malta.

[45] Adebote, D. A.; Oniye, S. J. and Muhammed, Y. A. (2008). Studies on mosquitoes breeding in rock pools on inselbergs around Zaria, northern Nigeria. J Vector Brone Dis, 45: 2128.

[46] Dejenie, T.; Yohannes, M. and Assmelash, T. (2011). Characterization of mosquito breeding sites in and in the vicinity of Tigray microdams. Ethiop J Health Sci, 21: 57-66.

How to cite this article:

Elhawary, N. A.; Soliman, M. A.; Seif, A. I. and Meshrif, W. S. (2020). Culicine mosquitoes (Diptera: Culicidae) communities and their relation to physicochemical characteristics in three breeding sites in Egypt. Egyptian Journal of Zoology, 74: 30-42 (DOI: 10.12816/ejz.2020.40783.1039). 


\section{مجتمعات البعوض (DIPTERA: CULICIDAE) و علاقتنها بالخصائص الفيزيائية والكيميائية في ثلاثة مواقع لتكاثره بمصر}

نورا عباس الهواري، محمد على سليمان، أمال إبراهيم سيف، وسام صلاح الدين مشرف

قسم علم الحيوان، كلية العلوم، جامعة طنطا، الغربية، جمهورية مصر العربية

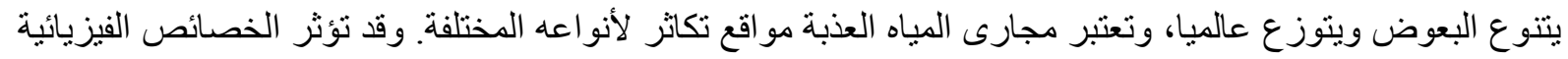

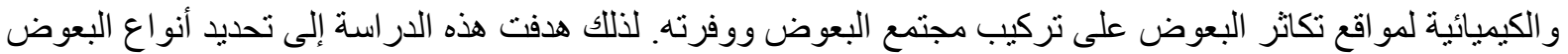

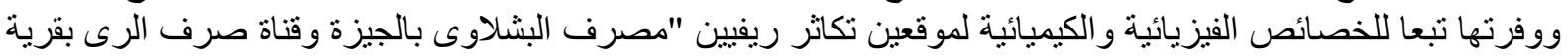

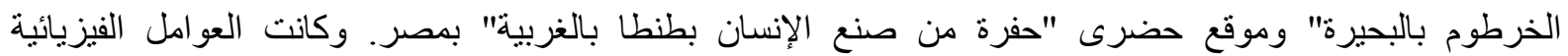

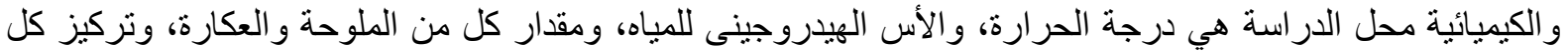

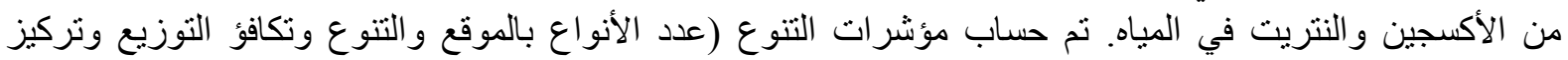

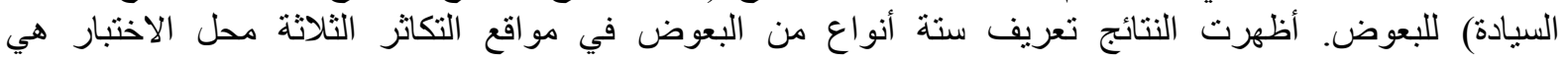
Cx. perexiguus , Cx. quinqueifasciatus و Cx. antennatus , Cx. univittatus و Culex pipiens"

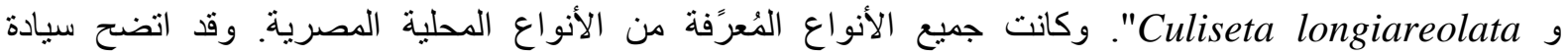

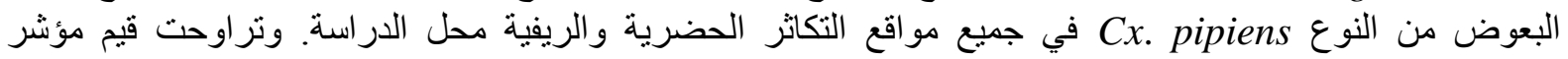

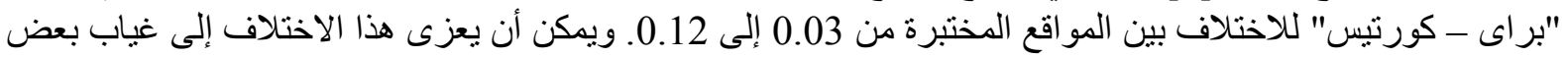

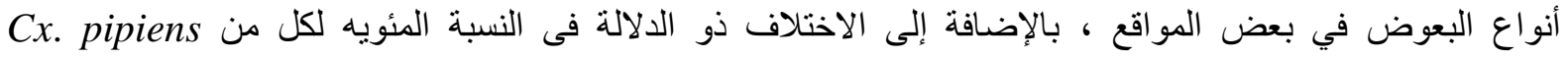

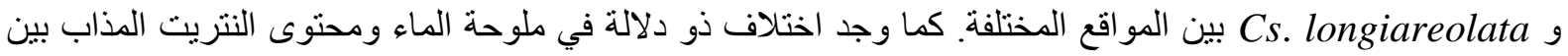

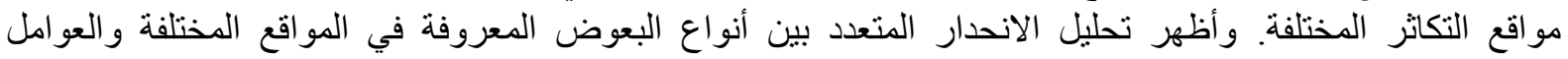
الفيزيائية و الكيميائية أن مقدار كل من الملوحة ومحتوى النيتريت و العكاره و الأس الهيدروجينى للمياه تعتبر عو المل رئيسية العيدية

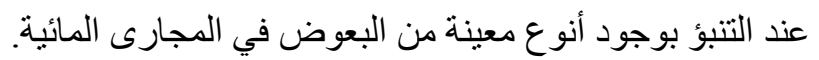

